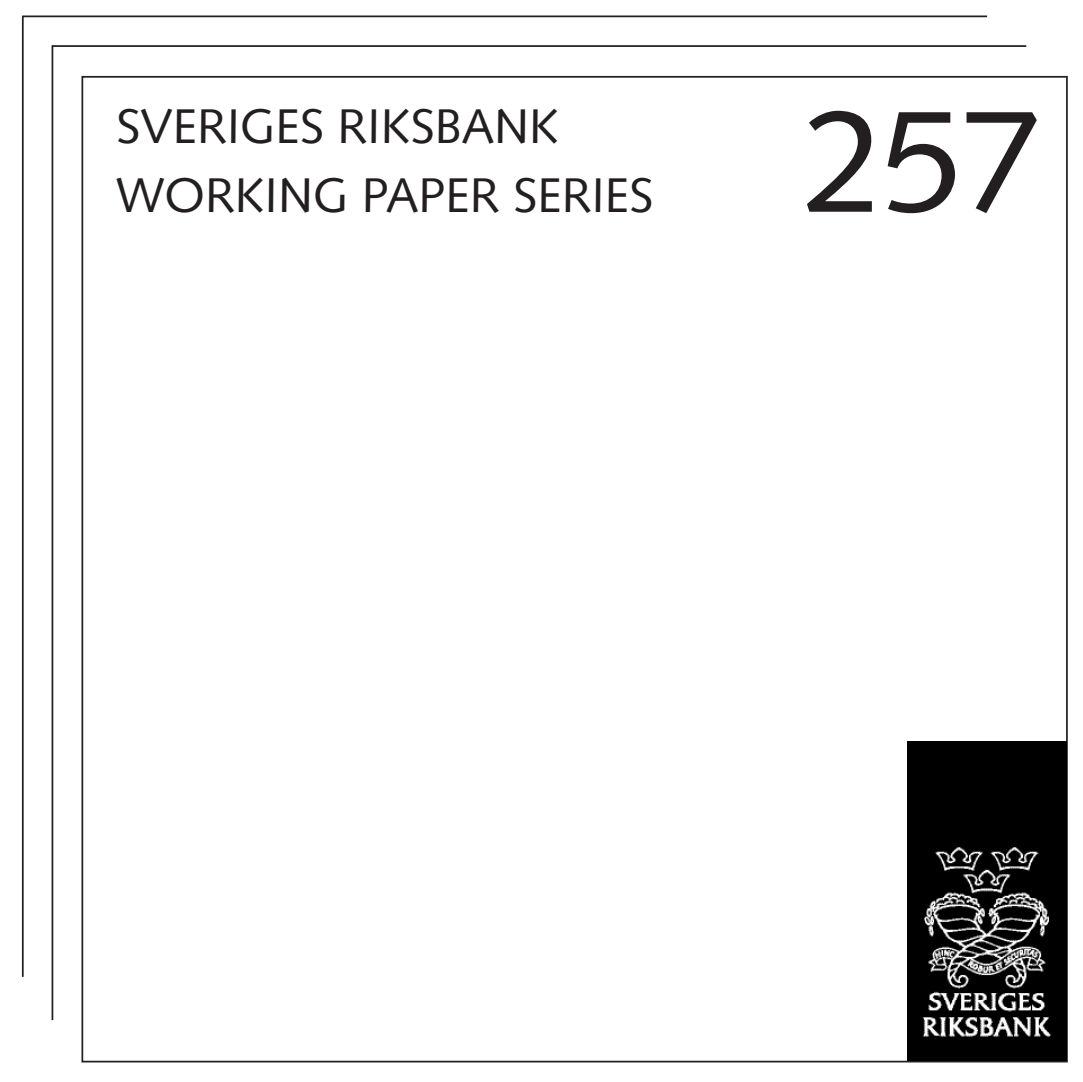

\title{
Collateralization, Bank Loan Rates and Monitoring: \\ Evidence from a Natural Experiment
}

Geraldo Cerqueiro, Steven Ongena and Kasper Roszbach 


\section{WORKING PAPERS ARE OBTAINABLE FROM}

Sveriges Riksbank •Information Riksbank • SE-103 37 Stockholm Fax international: +4687870526

Telephone international: +4687870100

E-mail: info@riksbank.se

The Working Paper series presents reports on matters in the sphere of activities of the Riksbank that are considered to be of interest to a wider public.

The papers are to be regarded as reports on ongoing studies and the authors will be pleased to receive comments.

The views expressed in Working Papers are solely the responsibility of the authors and should not to be interpreted as reflecting the views of the Executive Board of Sveriges Riksbank. 


\title{
Collateralization, Bank Loan Rates and Monitoring: Evidence from a Natural Experiment*
}

\author{
Geraldo Cerqueiro $^{\mathrm{a}}$, Steven Ongena ${ }^{\mathrm{b}}$, and Kasper Roszbach ${ }^{\mathrm{c}}$ \\ Sveriges Riksbank Working Paper Series, No. 257 \\ February 2012
}

\begin{abstract}
We study a change in the Swedish law that exogenously reduced the value of all outstanding company mortgages, i.e., a type of collateral that is comparable to the floating lien. We explore this natural experiment to identify how collateral determines borrower quality, loan terms, access to credit and bank monitoring of business term loans. Using a differences-in-differences approach, we find that following the change in the law and the loss in collateral value borrowers pay a higher interest rate on their loans, receive a worse quality assessment by their bank, and experience a substantial reduction in the supply of credit by their bank. The reduction in collateral value also precedes a decrease in bank monitoring intensity and frequency of both the collateral and the borrower, consistent with models in which the pledging of risky assets incentivizes banks to monitor.
\end{abstract}

Keywords: Collateral, credit rationing, differences-in-differences, floating lien, loan contracts, monitoring, natural experiment.

JEL Classification: D82, G21

\footnotetext{
* Corresponding author. We are grateful to Diana Bonfim, Fabio Braggion, Charles Calomiris, Sudheer Chava, Hans Degryse, Robert DeYoung, Scott Frame, Diana Hancock, Charles Kahn, Moshe Kim, Alberto Manconi, Ouarda Merrouche, Lars Norden, Andreas Pfingsten, Stefano Rossi, Jesús Saurina, Gustavo Suarez, Greg Udell, Patricio Valenzuela, participants at the American Finance Association meetings (Chicago), the European Finance Association (Stockholm) meetings, ASSA-IBEFA meetings (Denver), CEPR-ESSFM (Gerzensee), the Third Financial Stability Conference (Tilburg), the EUI Workshop on Financial Fragility (Florence), the Norges Bank Workshop on Financial Intermediation (Oslo), the CAREFIN Conference on Bank Competitiveness in the Post-Crisis World (Milano) and the Basel Committee on Banking Supervision RTF conference (Istanbul), as well as seminar participants at Erasmus University (Rotterdam), K.U. Leuven, and Maastricht University for helpful comments. Cerqueiro acknowledges the hospitality of Sveriges Riksbank while writing this paper, and financial support from the Portuguese Foundation for Science and Technology (grant PTDC/EGE-ECO/121186/2010). We thank Erik von Schedvin for very helpful discussions and excellent research assistance. The views expressed in this paper are solely the responsibility of the authors and should not be interpreted as reflecting the views of the Executive Board of Sveriges Riksbank. This paper can be downloaded at http://papers.ssrn.com/sol3/papers.cfm?abstract_id=1908097

${ }^{a}$ Universidade Católica Portuguesa, Palma de Cima, 1649-023 Lisbon, Portugal; Phone: +351 21 7214294, Fax: +351

21 7270252, E-mail: geraldo.cerqueiro@ucp.pt.

${ }^{\mathrm{b}}$ CentER - Tilburg University and CEPR, Department of Finance, Tilburg University, PO Box 90153, NL 5000 LE Tilburg, The Netherlands; Phone: +31 13 4662417, Fax: +31 13 4662875, E-mail: steven.ongena@uvt.nl;

${ }^{c}$ Sveriges Riksbank and University of Groningen, Research Division, Sveriges Riksbank, SE-103 37 Stockholm, Sweden; Phone: + 468 7870823, Fax: + 468 210531, E-mail: kasper.roszbach@ riksbank.se
} 


\section{Introduction}

Collateral is one of the most important features of many debt contracts. An extensive theoretical literature motivates the use of collateral to ameliorate information asymmetries between borrowers and lenders (Bester (1985); Chan and Thakor (1987); Boot, Thakor and Udell (1991); Boot and Thakor (1994); Lacker (2001)). The recent financial crisis vividly illustrates how such informational frictions can swiftly amplify into prohibitively high external finance premia that reduce firm investment and further depress economic activity (Bernanke and Gertler (1989), Bernanke, Gertler and Gilchrist (1996), Kiyotaki and Moore (1997), Matsuyama (2007)). Consequently, the importance of collateral is not only that it can relax credit constraints in general, but especially that it can do so when credit markets are tight. ${ }^{1}$

From the lender's perspective, collateral (that is internal) generally grants a higher position on the seniority ladder and therefore reduces the lender's expected losses given default. Recent research shows that collateral may thereby affect the incentives of banks to seek information about their prospective and current borrowers (Berglöf and von Thadden (1994); Rajan and Winton (1995); Repullo and Suarez (1998); Longhofer and Santos (2000); Manove, Padilla and Pagano (2001); Gorton and Kahn (2000)). The ability of banks to produce information about borrowers forms the centerpiece in modern theory of financial intermediation (Diamond (1984)). To the extent that both collateral and monitoring serve the purpose of reducing the information asymmetry between lender and borrower, it is also important to understand their interplay.

\footnotetext{
${ }^{1}$ In the words of one market participant: "Collateral is the grease that oils the lending system. [...] If the grease starts to freeze or run out, the loan cogs won't run as well." (Financial Times, November $28^{\text {th }}$, 2011, Financial System Creaks as Loan Lubricant Dries Up).
} 
In this paper, we aim to take a step forward in identifying the role that collateral plays in debt contracts and its impact on credit availability and bank monitoring. For this purpose, we exploit a change in law implemented in Sweden on January $1^{\text {st }}, 2004$, that reduced the value of company mortgages, a special collateral right commonly used in Sweden. ${ }^{2}$ Company mortgage refers to a claim on a floating pool of assets that, in many aspects, resembles the also widely observed floating lien in the U.S., the floating charge in the U.K., and the chattel mortgage in Australia.

The second ingredient in our empirical strategy is a rich dataset from a major Swedish bank that contains all records about its entire portfolio of business term-loan contracts. Our dataset includes regularly updated estimates of the value of the assets pledged to secure each loan, bank-internal records on borrower-specific lending limits and ratings, all adjustments to each individual loan interest rate, and all information needed to construct sensible measures of the intensity and frequency of bank monitoring activity. The unique natural experiment combined with the comprehensive bank data set enables us to address the common econometric identification challenges.

We study the effects of the change in law using a differences-in-differences method. Specifically, we assign the 3,537 loans, that are observed during 108,368 loan-months in our sample, to an affected, i.e., treated, and a non-treated group. Treated loans are those for which the borrower pledged the bank a company mortgage that is still outstanding around the change in the law. Importantly for our purposes, we are able to identify the causal relationship from collateral to the interest rate because all business term loans carry a quarterly adjustable interest rate while all other contract terms are fixed.

2 The average volume of outstanding company mortgages pledged by Swedish incorporated companies in 2003 was 19 percent of their total debt and 58 percent of their debt to financial institutions. Calculations by the authors are based on balance sheet data from the Swedish credit bureau. Debt to financial institutions includes both short-term and long-term loans. 
We establish four main findings, which we obtain comparing the same treated loans and borrowers before and after the change in law. First, following the change in the law, the bank reduces the assessed value of the outstanding collateral. For example, the collateral coverage ratio recorded by the bank drops by 4 percentage points on average following the change in the law. Second, the bank reduces its internal credit limit to borrowers with collateralized business loans by 13 percent and downgrades these borrowers by almost 2 notches on a 21 -grade scale. Third, the bank increases the interest rate on the same treated loan by 24 basis points. Even after controlling for the reassessment of borrower quality by the bank, the increase in the loan rate is approximately 20 basis points (which, recall from the first finding, corresponds to a 4 percentage point decline in the collateral coverage ratio). Fourth, following the change in the law, the bank significantly reduces the intensity and frequency of its monitoring of the condition of both the collateral and the borrower.

Taken together, these results suggest that collateral is important for the bank and valuable for the borrower. Following a loss in collateral value, the bank charges a higher interest rate on the loan, decreases the availability of credit, worsens its quality assessment of the borrower, and reduces its monitoring efforts of collateral as well as of the borrower.

Overall, our findings are consistent with empirical work by Haselmann, Pistor and Vig (2010), who show that the strengthening of legal rules designed to protect individual creditors' claims outside bankruptcy increased bank lending in transition countries; ${ }^{3}$ and with Berger, Frame and Ioannidou (2010), who - even though they do

\footnotetext{
${ }^{3}$ La Porta, Lopez-de-Silanes, Shleifer and Vishny (1997), La Porta, Lopez-de-Silanes, Shleifer and Vishny (1998), Levine (1999), Djankov, La Porta, Lopez-de-Silanes and Shleifer (2003), Beck, Demirgüç-Kunt and Levine (2005), among others, provide evidence on the importance of the law, its origin and the legal system, for financial arrangements and economic performance. Liberti and Mian (2010) document the importance of collateral for economic development in this context.
} 
not study the effect of collateral on loan pricing and credit availability - document that collateral serves primarily as a contractual device to solve moral hazard problems. Our evidence also suggests collateral may complement monitoring. This finding is in line with Rajan and Winton (1995), who model how collateral can improve lenders' incentives to monitor when the value of the assets pledged is risky.

Using as a natural experiment a reform in India that improved the ability of lenders to access the collateral of the firm, Vig (2011) investigates its effect on the corporate debt structure. He finds that corporate secured debt, total debt, debt maturity, and asset growth declined and liquidity hoarding increased, especially for firms with a higher proportion of tangible (fixed) assets. Hence, the strengthening of creditor rights in India introduced a liquidation bias and firms altered their debt structures to contract around it. Complementary to Vig (2011), our study focuses on the immediate bank response to a reduction in the value of outstanding company mortgages in terms of loan pricing, borrower ratings, lending limits and monitoring activities. ${ }^{4}$

More generally, our study contributes to the literature by providing an actual estimate of the value of creditor seniority. Modern corporate finance theory recognizes debt seniority as a key contractual feature that affects investment incentives. ${ }^{5}$ However, direct empirical evidence on the actual value of debt seniority is scant. Our quasi-natural experiment setting based on an exogenous decrease in the value of a special priority right claim offers an opportunity to provide such evidence.

\footnotetext{
${ }^{4}$ The 2005/06 reforms of the Italian bankruptcy law that strengthened the firms' rights to renegotiate outstanding deals with creditors similarly increased the cost of funding for small and medium sized firms, while the law simplifying the procedure of liquidation decreased it (Rodano, Serrano-Velarde and Tarantino (2011)).

5 Smith and Warner (1979) argue that secured debt can limit the firm's ability to engage in asset substitution, while Stulz and Johnson (1985) show how secured debt can mitigate underinvestment problems. Berkovitch and Kim (1990) argue that project finance can help resolve investment incentive problems. Barclay and Smith (1995) find that the use of secured debt and other high priority debt-like instruments (e.g., leasing) should be increasing in the likelihood of agency conflicts. More recently, Hackbarth, Hennessy and Leland (2007) show that placing bank debt senior in the firm's priority structure fully exploits interest tax shield benefits.
} 
The remainder of this paper is organized as follows. Section 2 relates our paper further to the literature. Section 3 describes the change in the company mortgage law. Section 4 details the data, variables, and empirical methodology. Section 5 discusses the impact of the change in the law on collateralization, loan rate, borrower limit and internal rating, and bank monitoring effort. Section 6 concludes.

\section{Literature Review}

\section{a. Collateral and Loan Contracting}

An extensive theoretical literature emphasizes the role of collateral as an effective loan-contracting tool aimed at ameliorating information asymmetries in the credit market. ${ }^{6}$ Collateral may compensate either for ex ante adverse selection (e.g., Bester (1985); Chan and Thakor (1987); Boot, Thakor and Udell (1991)) or for ex post moral hazard problems (Boot and Thakor (1994)). The two sets of theories offer opposite predictions regarding the relation between the incidence of collateral and the observable quality of the borrower. While ex post theories predict that riskier borrowers are more likely to be required to pledge collateral, ex ante theories postulate that unobservably safer borrowers pledge collateral. Not surprisingly, the empirical evidence is equally mixed with this respect. Overall, the available evidence seems to suggest that riskier borrowers are more likely to pledge collateral (e.g., Berger and Udell (1990); Berger and Udell (1995); Harhoff and Körting (1998); Jiménez, Salas and Saurina (2006); Berger, Frame and Ioannidou (2010)).

A related empirical question that has received much attention recently is the relation between collateral and loan rates. This is a challenging empirical question, since loan contract terms may be determined simultaneously (as was already recognized by Melnik

\footnotetext{
${ }^{6}$ Freixas and Rochet (2008) and Degryse, Kim and Ongena (2009) review theory and empirical evidence on collateral and bank-firm relationships.
} 
and Plaut (1986) for example). Some studies have attempted to address this concern by estimating models of simultaneous equations (Dennis, Nandy and Sharpe (2000); Brick and Palia (2007); Bharath, Dahiya, Saunders and Srinivasan (2007)). Specifically, these studies employ an instrumental variables approach to estimate the effect on the loan rate of a binary measure of collateral, assuming that the relationship between the two variables is unidirectional. Although they employ different U.S. datasets, all three studies find a positive and statistically significant effect of the collateral dummy on the loan rate, which they interpret in light of ex ante collateral theories.

\section{b. Collateral and Bank Monitoring}

While collateral is often regarded as a contractual device to mitigate a borrower's adverse incentives, a recent literature deals with the agency problems on the lender's side. From the lender's perspective, inside collateral grants a higher position on the seniority ladder and therefore reduces the lender's expected losses given a borrower's default.

A substantial literature demonstrates that seniority improves a lender's incentives to monitor the firm and liquidate the firm if it gets in financial distress (e.g., Berglöf and von Thadden (1994); Repullo and Suarez (1998); Gorton and Kahn (2000); Park (2000)). Longhofer and Santos (2000) for example show that seniority encourages the formation of banking relationships and thereby improves the banks' incentives to monitor. The intuition for their result is that in bad states the investment in monitoring yields higher returns when the lender is senior. In Park (2000), seniority ensures that the lender appropriates the full return from monitoring when the borrower's moral hazard problem is severe. Rajan and Winton (1995) argue that in the presence of other claimants monitoring is valuable because it allows the lender to demand additional 
collateral if the firm is in distress. As a result, collateral should improve a bank's monitoring incentives. ${ }^{7}$

To the best of our knowledge, Ono and Uesugi (2009) is the only other empirical study that attempts to test the relation between collateral and monitoring. Using a survey dataset of Japanese small and medium enterprises, Ono and Uesugi (2009) find that firms that more frequently submit documents to their main bank are less likely to pledge collateral. ${ }^{8}$

We aim to take a step forward in identifying the value of collateralization and its impact on borrower quality and bank monitoring. To this end, we exploit a change in the law affecting the value of collateral as a unique natural experiment and employ a differences-in-differences approach to analyze a dataset containing all business term loans granted by a major Swedish bank. Our empirical analysis in this way combines a unique experimental setting and a comprehensive dataset to overcome the fundamental econometric identification challenge that existing studies have partly left unaddressed.

\section{The Swedish Company Mortgage}

The company mortgage is a security interest in a floating pool of a company's personal property assets. In this respect, company mortgages resemble the floating lien in the United States, the floating charge in the U.K., and the chattel mortgage in Australia. ${ }^{9}$ Many other jurisdictions recognize comparable collateral concepts.

\footnotetext{
${ }^{7}$ Manove, Padilla and Pagano (2001) argue that collateral can weaken the bank's incentive to evaluate the profitability of a planned investment project. We note that while their model focuses on screening incentives, the focus of our empirical investigation is bank monitoring.

${ }^{8}$ Ono and Uesugi (2009) measure the incidence of collateral with an indicator variable. About 72 percent of the firms in their sample responded that they pledged collateral to their main bank. They measure monitoring with an ordinal variable that ranges from one (documents submitted to the borrower once every 1-2 months) to four (documents submitted on an annual basis). In a related study, Argentiero (2009) employs data from Italy to analyze the relation between collateral value and firm screening, measured as the number of bank employees in the lending branch scaled by the loan amount.

${ }^{9}$ In the United States, a lien typically refers to so called non-possessory collateral interests. In many other common-law countries, liens tend to refer to possessory collateral. A chattel pledge typically refers
} 
Company mortgages and their equivalents in other jurisdictions have been popular as collateral for two main reasons. First, chargees accept collateral that covers not only current but also future assets in a pre-defined range. Second, chargors obtain contractual benefits from their lenders with the pledged assets while maintaining their freedom to use the assets in the normal course of their business (in this way avoiding the inconvenience of requiring permission from their lenders to engage in individual transactions). In terms of seniority, floating charges rank above unsecured creditors, but rank below both holders of fixed collateral and some classes of preferential creditors. ${ }^{10}$

Swedish company mortgages enable businesses to pledge particular categories of "personal" (i.e., moveable) property as collateral. "Real" (i.e., immovable) property, such as land, buildings, and machinery that can be mortgaged otherwise, or financial assets such as cash, bank deposits, stocks, and bonds, were outside the scope of company mortgages before 2004 (see below).

An official register maintained by the Swedish Companies Registration Office records each company mortgage. The holder of a company mortgage can voluntarily list himself in the register. Registering a company mortgage does not guarantee that nominally sufficient collateral is present in the business. For example, the registration office does not have any responsibility to verify the degree of collateral coverage. If a business has registered multiple company mortgages, these claims have relative seniority ordering depending on the calendar date of their registration. Businesses pay a

to a security concept where the chattel is brought under the control of the creditor, for example through an approved third-party warehouse. Berger and Udell (2006) report that in 2003 the stock of total asset-based loans in the U.S. was about $\$ 300$ billion, compared to a stock of commercial and industrial loans of about $\$ 900$ billion (inclusive of bank asset-based loans).

${ }^{10}$ Gennaioli and Rossi (2009) show that in the presence of strong creditor rights the optimal contractual resolution of financial distress involves the use of floating charges. Franks and Sussman (2005) document that floating charges work well as the basis of foreclosure of small and medium-sized U.K. companies, while Djankov, Hart, McLiesh and Shleifer (2008) generalize this result to a broad set of countries. 
one percent annual register fee over the outstanding amount of the company mortgage plus a nominal fee upfront. For further details on the institutional setting of the Swedish banking market, we refer to the online Appendix.

Before 2004, company mortgages were special priority rights claims that could be invoked by its holder not only in case of a bankruptcy - as is the case with any normal, not legally prioritized claim, as well as with many senior debt claims - but also in the case of distraint, i.e., the seizure of assets by a third party. This special priority right raised the value of the company mortgage versus claims that had: (1) Normal priority rights, and hence are ranked below special priority rights, such as costs incurred in bankruptcy or reconstruction procedures, taxes and most of the wage claims by employees (a limited part has special priority rights); or (2) no priority rights.

On January $1^{\text {st }}, 2004$, the Law on Company Mortgages that regulates the company mortgage (henceforth, "the Law") was changed. ${ }^{11}$ The special priority rights of the company mortgage converted into normal priority rights and consequently the security interest obtained by means of a company mortgage could only be invoked in the case of bankruptcy. ${ }^{12}$ While the group of assets that could be pooled into a company mortgage now also included cash, bank deposits, financial assets, and real estate, the share of total eligible assets was reduced from $100 \%$ to $55 \%$ of what remains after creditors with preferential rights have been paid. ${ }^{13}$ As a result, the company mortgage lost in value in most cases. In fact, the official records of the Parliamentary Committee on Civil Law

${ }^{11}$ The "Lag (2003:528) om företagsinteckning" replaced the "Lag (1984:649) om företagshypotek".

12 Sweden adopted an auction bankruptcy system that requires the immediate sale of the company (Thorburn (2000), Strömberg (2000), Eckbo and Thorburn (2003)). Eckbo and Thorburn (2009) compare the Swedish auction bankruptcy system with U.S. Chapter 11.

${ }^{13}$ Other elements of the change in the law were an abolishment of the normal priority rights of the taxes (to give government institutions incentives to cooperate in bankruptcies and reconstructions) and a quantitative reduction of the normal priority rights of wage claims. To compensate for the latter reduction, the government increased the wage amount it guaranteed with public funds. 
mention that collateral of lower quality will provide better incentives to banks to assess the profitability of firms rather than the availability of collateral when granting credit. ${ }^{14}$

Yet, lawmakers did not expect the change in law to result in higher collateralization requirements because collateral utilization was supposedly at its maximum already. ${ }^{15}$ The Swedish Banking Association, however, commented on the proposed change in the law that it expected collateralization requirements to increase, given the key role played by collateral for Basel II capital requirements. The Association also expected interest rate margins to increase.

Seemingly, the objective of the change in the law was twofold. First, it aimed at improving the possibilities for temporally troubled but essentially solvent and viable businesses to avoid inefficient liquidation by timely reorganization. Second, it aimed at weakening the lenders' incentives to secure collateral rather than to spend effort screening and reviewing the borrowers. While expanding the pool of assets underlying of the company mortgage meant that changes in the composition of assets (during borrower distress for example) would matter less for lenders (by abating the borrowers' incentives to game the assets and assuring lenders their collateral value), abolishing the special priority rights of the company mortgage implied that any lenders' collateral claim would now require the borrower's actual bankruptcy. ${ }^{16}$

${ }^{14}$ Sveriges Riksdag, Lagutskottets Betänkande (Report by the Swedish Parliamentary Committee on Civil Law) 2002/03: LU17, page 10: "Worse collateral for the credit provider would give the credit provider reasons to both focus more on the borrower's possibility to repay, and to intervene earlier and be more active, which according to the government should facilitate company reconstructions", i.e., debt restructurings. Indeed, data from the Swedish Companies Registration Office displays a sharp reduction in the number of company mortgages registered following the law. From 2003 to 2004, the number of company mortgages registered (i.e., the stock) decreased by $32 \%$.

${ }^{15}$ Lawmakers also did not expect any detrimental effects of the change in the law on start-up firms because primarily more mature businesses in their expansionary phase employ the company mortgage (Source: Official Documents of the Parliamentary Committee on Civil Law dealing with the change in the law, Sveriges Riksdag, Lagutskottets Betänkande 2002/03:LU17).

16 The 2004 change in the law was mostly "reversed" on January $1^{\text {st }}$, 2009. Currently lacking the required data, we leave the study of this reversal for future research. Among the economic arguments put forward by the government for this reversal were anecdotic reports that companies found it more difficult to obtain credit, and that credit had become more expensive, especially in the less densely populated areas 
Given the quasi-experimental setting this change in the law provides, involving an exogenous and rather sudden loss in the value of all company mortgages, we study its impact on all outstanding loans and a bank's collateralization requirements, loan rates and monitoring intensity. ${ }^{17}$

\section{Data, Variables, and Empirical Methodology}

\section{a. Data}

For our analysis, we use a unique and comprehensive database containing all corporate accounts of a major Swedish commercial bank (henceforth, "the bank"). ${ }^{18}$ The database contains all loan files the bank maintains for each borrower at a monthly frequency between 2003:01 and 2006:12. ${ }^{19}$ From this database, we extract all business term loans, i.e., loans with a quarterly repayment schedule. In December of 2003, these business term loans represent $6.5 \%$ of the bank's loan portfolio. Important for our purposes, business term loans can be either unsecured or secured, and company mortgages can only be pledged to secure this particular type of loan. ${ }^{20}$ The loans carry a floating reference interest rate with a mark-up that is adjustable on a quarterly basis. For

of Sweden. Many governmental agencies, industry lobbies and legal specialists on the other hand in their solicited written comments on the proposed reversal argued in vain that too little time had passed for a serious evaluation of the 2004 change in the law. The government pushed the reversal arguing that businesses would have more assets available as collateral and thus better access to credit. Worse incentives for lenders to monitor and for borrowers during bankruptcy received only short shrift this time. In fact, the government explicitly expected bankruptcy to become more likely and reorganization less likely. The 2009 change in the law did not involve a complete reversal of the 2004 change as it also totally abolished the government's normal priority rights for paid-out guarantees on wage claims. A budget proposal to cover the expected reduction in government revenues in bankruptcy procedures, amounting to 298 million Swedish kroner (about 38 million U.S. dollars in 2009) per year therefore accompanied the change in the law.

${ }^{17}$ Although an inquiry into the merits of the company mortgage and the role of preferential collateral rights preceded the change in law, the final numerical details of the bill that Parliament later voted on were announced in January 2003. The parliamentary term for amendments closed on March $6^{\text {th }}, 2003$ and Parliament passed the bill on June $6^{\text {th }}, 2003$.

${ }^{18}$ Degryse, Ioannidou and von Schedvin (2011) employ the same dataset as we do to investigate the non-exclusivity of Swedish loan contracts.

${ }^{19}$ Our dataset starts in April 2002. However, information on collateral values is only available in January 2003.

${ }^{20}$ The internal classification of loans by the bank is such that loans with a variety of fixed collateral make up a range of separate loan categories. 
our purposes, it is important that no other contract feature than the interest rate paid on the loan can be altered in response to a change in collateral values.

We supplement the bank's data with information from the Swedish Companies Registration Office. The Office maintains registered information on all company mortgages pledged in Sweden. The dataset we have access to tracks all company mortgages registered between 2000 and 2008. For each company mortgage, we obtain the date of registration and the amount. ${ }^{21}$ The identity of the holder of the mortgage letter is not always known because this information is not required by the Office. However, the holder often provides his identity voluntarily when filing the company mortgage, because it allows for notification when collateral becomes callable.

\section{b. Variables}

Table 1 describes the dependent variables used in this study and presents some descriptive statistics for each variable: The mean, standard deviation, and number of observations. We analyze three sets of variables. First, we analyze some terms specified in each individual loan contract: The collateral value, the collateral coverage ratio, and the loan rate. The collateral value is the bank's own estimate of the assets pledged to secure that particular loan. The collateral value is updated occasionally as a result of the bank's revaluation of the assets pledged. On average, businesses pledge $€ 49,950$ worth of collateral. ${ }^{22}$ The collateral coverage ratio is defined as the collateral value scaled by the exposure (i.e., the outstanding balance) of the loan and equals 46.6 percent on average. ${ }^{23}$ The coverage ratio is an important determinant of the lender's recovery rate

${ }^{21}$ Between 2000 and 2003, the median amount registered in a company mortgage is 47,855 SEK (about $\$ 7,000$ in December, 2003).

${ }^{22}$ Some variables were expressed in Euros by the bank, while other data was in SEK. A smaller number of variables were available both in SEK and in EUR. We converted variables expressed in SEK into EUR at the exchange rate used by the bank.

${ }^{23}$ The collateral value registered by the bank cannot be higher than the outstanding liability of the borrower. This implies that when a loan is fully secured, there is some time variation in the collateral 
upon a loan default (Khieu and Mullineaux (2009); Altman and Kalotay (2010)). The average loan rate, computed as the annualized interest rate of the loan, equals 6.57 percent. $^{24}$

Second, we employ two measures of the bank's own assessment of the borrower's creditworthiness. The first is the internal credit rating of the borrower, which ranges from 0 (highest risk category) to 20 (lowest risk category), with a mean of 9.28. Only borrowers with exposure levels above a certain fixed pre-determined threshold are assigned an internal rating. ${ }^{25}$ To circumvent the problem that these ratings are missing for almost $40 \%$ of the borrowers in our sample, we also analyze the borrower's internal credit limit. The internal limit is the maximum amount the loan officer is entitled to lend to the firm. The loan officer can decide to lend to the firm only some fraction of this limit value, and this is most often the case in our data. An increase in this credit limit requires approval by a hierarchical superior, i.e., a credit committee. As with the internal ratings, this internal limit is reviewed periodically and is generally not directly observable by the borrower. In our sample, borrowers have an average internal credit limit of $€ 499,000$.

Third, we propose several measures of bank monitoring activity. We separate these measures into collateral-based and borrower-based measures. Collateral-based monitoring relates to the revaluation of the assets pledged as collateral, while borrower-

value (i.e., as the loan is being paid back) that is mechanically driven by this restriction (the collateral coverage ratio does not suffer from the same drawback). In our sample, $37 \%$ of the loans are fully secured. However, our empirical methodology employs within-loan estimators (see below) that should account for such mechanical variation in the data. In unreported regressions (available from the authors upon request), we show that our main results further remain similar when we remove the mechanical variation in collateral values.

${ }^{24}$ As all our econometric models contain a comprehensive set of time dummies, analyzing the loan rate or the loan spread is equivalent.

${ }^{25}$ For confidentiality reasons, we cannot disclose what the threshold is. Clients with an exposure below this threshold are assigned a so-called "behavioral rating" which is based on account behavior. We do not have access to the behavioral ratings. Evidence on the importance of indications from account activity for loan pricing is provided by Norden and Weber (2010) (see also Mester, Nakamura and Renault (2007)). 
based monitoring pertains to the review by the bank of the borrower's condition. In the context of collateral-based monitoring, we further distinguish between how often the collateral is revalued by the bank (monitoring frequency) and the magnitude of such revaluations (monitoring intensity). ${ }^{26}$

We measure monitoring intensity as the absolute value of the percentage change in the collateral value between two consecutive months. The mean annualized change in collateral value equals 6.05 percent. We also analyze the magnitude of changes in the collateral coverage ratio as an alternative measure of collateral monitoring intensity. If the bank's monitoring incentives of a particular loan are tied to its risk exposure, then monitoring incentives should be tied to the coverage ratio, rather than to the absolute collateral value. The mean change in the collateral coverage ratio is 2.9 percent.

Besides considering the magnitude of the revaluations of the assets pledged as collateral, we also analyze the frequency with which loan officers undertake such revaluations. To this end, we calculate the number of collateral revaluations made per year. As before, we compute this measure for both the collateral value and the collateral coverage ratio. The average annual number of revaluations ranges between 2 and 2.3, depending on the measure chosen.

While some infrequent additions or subtractions of collateral could also result in changes in collateral value, we note that in the context of company mortgages they should be mostly a consequence of loan officer monitoring and actions. As explained in Section 3, a company mortgage is a claim on a floating pool of a predetermined set of assets. Because the composition of the pool may change through time, the loan officer

\footnotetext{
${ }^{26}$ Our monitoring measures borrow largely from the literature on corporate governance and corporate control. For instance, corporate governance studies often employ the frequency of board meetings as a proxy for CEO monitoring (Vafeas (1999)). The literature on venture capital financing emphasizes the staging of capital infusions as an important control mechanism for venture capitalists (Gompers (1995)). We conjecture that both the number of financing rounds and the amount invested in each round are correlated with monitoring effort.
} 
needs to revaluate the company's assets in order to update its estimate of the collateral value. Therefore, we presume that larger and more frequent asset revaluations reflect a higher monitoring effort by loan officers in evaluating the assets pledged as collateral.

Finally, we compute a measure of borrower monitoring based on the frequency with which the bank revises the client's situation. Specifically, we calculate the time to the next review as the number of months until the next planned review date. The average time to the next revision is slightly above 10 months but varies widely across firms, ranging between 1 and 15 months. The revision outcome may be a change in the collateral value, the loan rate, the internal limit, and/or the internal rating. The revision of the client's situation requires that the loan officer collects and processes new information about the customer. This leads us to hypothesize that revisions that are more frequent are consistent with a more intensive monitoring effort.

\section{c. Empirical Methodology}

We examine the effects of the change in the law using a differences-in-differences approach. This methodology compares the effect of the change in the law on two groups: A group that is directly affected by the event, which we will call "the treated group", and a group that is unaffected by the event, which is the control group or nontreated group. The differences-in-differences approach then relies on measuring the differential effect of the change in the law across the two groups. ${ }^{27}$

Our identification strategy exploits the change in the law in 2004 that decreased the value of company mortgages. We define the treated group as all borrowers that pledged

\footnotetext{
${ }^{27}$ The change in the law could affect indirectly the control group if, for instance, the bank changes its pricing policy. However, our methodology differences out such aggregate effects to the extent that they affect both the treated and the control groups.
} 
at least one company mortgage to the bank before $2004 .{ }^{28}$ Since the change in law focused only on this particular type of collateral, we presume that borrowers that never registered a company mortgage during our sample period should not have been directly affected by the change in the law. Therefore, we assign these borrowers to the nontreated group. We further require that the non-treated borrowers have loans outstanding that originate prior to the change in the law and mature thereafter (relaxing this requirement by including all loans that are outstanding during the sample period does not alter results). We dropped borrowers that pledged a company mortgage to any other entity.

To evaluate the effect of the change in law, we estimate the following regression model:

$$
y_{i t}=\alpha_{i}+\lambda_{t}+\text { Breated }_{i} \times \text { After }_{t}+u_{i t}
$$

where $i$ indexes loans or borrowers (depending on the specification), ${ }^{29}$ and $t$ indexes time, i.e., year*month. The dependent variable is $y_{i t}$ and the error term is $u_{i t}$.

The main explanatory variable of interest, Treated ${ }_{i} \times$ After $_{t}$, results from the interaction of two terms. The first, Treated ${ }_{i}$, defines the treated group (as opposed to the non-treated group). Specifically, this dummy indicates whether the firm had a company mortgage pledged to our bank before the change in the law became effective on January $1^{\text {st }}, 2004$. This variable captures differences between the treated and non-treated groups

${ }^{28}$ Recall that the company mortgages dataset we obtain from the Swedish Companies Registration Office starts in 2000. The fraction of firms that pledged multiple company mortgages in the same year to our bank is $3.4 \%$.

${ }^{29}$ Some firms have more than one loan at the bank so we can use the loan as a cross-sectional unit. We then cluster the standard errors at the borrower level to address the potential correlation between loans belonging to the same borrower (Bertrand, Duflo and Mullainathan (2004)). 
before the change in the law. ${ }^{30}$ In our sample, the number of treated and non-treated borrowers is 252 and 3,285 , respectively.

The second term, After ${ }_{t}$, equals one for the periods following the change in the law (i.e., 2004:01 to 2006:12), and equals zero otherwise (2003:01 to 2003:12). This variable captures differences for the non-treated group before and after the change in law. To the extent that the change could have been anticipated and loan contracts and bank assessments adjusted prior the effective implementation date, we are likely to underestimate the impact of the change in the law. However, because the bill was passed in June 2003, the potential for anticipation was limited. In unreported robustness checks, we confirm that anticipation effects are quantitatively and qualitatively unimportant.

The variable resulting from interacting the two terms, Treated $_{i} \times$ After $_{t}$, measures the differences-in-differences effect. Specifically, it measures the differential effect of the change in the law across firms that had pledged and firms that had not pledged company mortgages.

The model includes both individual fixed effects $\left(\alpha_{\mathrm{i}}\right)$ and time fixed effects $\left(\lambda_{t}\right)$. The inclusion of these fixed effects is crucial to absorb sources of heterogeneity. On the one hand, the individual fixed effects control for time-invariant differences between the treated and non-treated groups. This ensures that our estimates are not plagued by bias due to nonrandom selection into treatment (i.e., a firm's decision to pledge a company mortgage). ${ }^{31}$ On the other hand, the time fixed effects control for aggregate changes at the institution (or macro) level.

\footnotetext{
${ }^{30}$ We cannot include neither one of these two variables separately in the specification, because Treated is spanned by the individual fixed effects, while After is spanned by the time fixed effects.

31 Self-selection could be motivated theoretically by adverse selection in credit markets (Bester (1985); Chan and Thakor (1987); Boot, Thakor and Udell (1991)). In these models, lenders offer a menu of contracts that trade off the degree of collateralization and the loan rate. The design of these contracts
} 


\section{The Impact of the Change in the Law}

\section{a. Collateralization, Loan Rate, Borrower Limit and Internal Rating}

\section{Main Results}

We start by documenting the effect of the change in law on the borrowers' credit terms. Specifically, we analyze how the exogenous decrease in collateral value following the 2004 change in the law affects the loan's collateral value and coverage ratio, interest rate, as well as the borrower's internal limit and rating. Table 2 displays the averages for the non-treated and treated groups, before and after the change in law, for the five aforementioned variables. The table also provides differences of means tests and differences-in-differences estimates. We note that the estimates of these differences can also be obtained by estimating the pooled version of equation (1), where the individual effects $\left(\alpha_{\mathrm{i}}\right)$ and time effects $\left(\lambda_{\mathrm{t}}\right)$ are replaced by the Treated $_{i}$ and After $_{t}$ variables, respectively. Therefore, when interpreting the differences-in-differences estimates displayed in Table 2, one should keep in mind that they do not account for unobserved heterogeneity across loans, firms, and time.

Before the change in the law, borrowers that had pledged company mortgages had credit terms that were virtually identical to those of borrowers in the non-treated group. The treated borrowers pay slightly higher loan rates and post more collateral than the non-treated, but these differences are not statistically significant. We note that the only significant difference between the two groups is that the treated borrowers had significantly lower internal ratings.

ensures that observationally equivalent applicants with higher-quality projects choose secured debt with lower loan rates, while those with lower-quality projects self-select into unsecured debt with higher loan rates. Because we include loan (or borrower) fixed effects, we control for firm type, and simultaneously account for the role of collateral as a screening device and address the selection of the remaining loan contract terms. Therefore, our methodology allows us to isolate the causal effect of a shock to collateral value on both the loan rate and monitoring incentives. 
Most interesting is the finding that the 2004 change in the law brought about a significant wedge between the two groups. Specifically, borrowers with outstanding pledged company mortgages experienced a sharper decrease in collateral value, a significant relative increase in the loan rate, and deterioration in their internal limits.

The results in Table 2 do not account for individual unobserved heterogeneity, and hence they could be biased if, for instance, borrowers select their loan contracts based on their type. To assess the significance of the change in law further, we thus rely on the differences-in-differences estimates shown in Table 3. These estimates are obtained from the model in equation (1), which includes sets of fixed effects for both the crosssectional (i.e., loans or borrowers) and time (i.e., year*month) units. The results indicate that the value of the assets pledged as collateral by the treated group decreased by a substantial amount (for example at the mean of 49,950 euros, collateral value drops to 23,595 euros). Part of this effect is due to a larger reduction in outstanding loan amount for the treated group. However, the decrease in collateral value is sharper than the decrease in the individual loan exposure for the treated group, which translates into a decline in their collateral coverage ratio of more than four percentage points after 2004. Hence, we confirm that the change in the law is perceived by the bank to result in a loss of collateral value.

The decrease in the coverage ratio caused by the reduction in the value of outstanding collateral increases the bank's expected losses. Consistent with this view, the treated group also experienced an average 24 basis points increase in their loan rate, a reduction in their internal credit limit by 13 percent and a downgrade in their internal rating by almost 2 levels on a 21-level scale, vis-à-vis the untreated group. ${ }^{32}$

\footnotetext{
32 The reduction in the credit limit is consistent with a (leftward) shift in the credit supply to borrowers that suffered the decrease in collateral value. In unreported regressions, we also analyze the borrower's total lending scaled by this internal limit. We find a statistically significant reduction in this
} 
Following the change in the law, we observe a contemporaneous decline in the collateral coverage ratio of about 4 percentage points and an increase in the loan rate by 24 basis points, for the same loan and borrower. However, the change in the value of the company mortgage also affects borrower limit and rating we found. Consequently, in Table 4 we introduce these internal bank measures of borrower risk in specifications for the 3,491 and 2,083 loans, respectively, for which we have these measures. Controlling for the deterioration in borrower quality - as assessed by the bank - slightly lowers the increase in the loan rate after the change in the law, but the impact remains statistically significant and economically relevant (the estimated differences-in-differences coefficients "drop" from 19 to 18 and from 39 to 33 basis points, respectively). ${ }^{33}$

These estimates suggest that for the same loan contract (and accounting for changes in borrower quality following the change in the law) the bank "charges" the borrower on average around 6 basis points for each percentage point decrease in collateral coverage ratio. This finding is consistent with the observation that collateralization (and the degree of subordination) is a key determinant of recovery on defaulted debt (e.g., Khieu and Mullineaux (2009); Altman and Kalotay (2010)). Consequently, our results suggest that posting collateral may substantially reduce the loan rate at the individual loan contract level.

ratio following the change in law. This result suggests that loan officers are being even more stringent than the bank in imposing credit constraints to these treated borrowers (assuming no effect on the demand side).

${ }^{33}$ The estimated coefficients for the borrower risk measures are surprisingly small. For instance, the coefficient on the internal rating variable in the last column of Table 4 suggests that a borrower that goes from the highest to the lowest risk category benefits from a decrease in the loan rate of about 63 basis points. We provide two explanations for this finding. First, there is limited variation in the internal rating for the same borrower. Second, our specification does not allow for a potential non-linear response of the loan rates to a change in the rating. If we substitute the internal rating with dummies for separate rating categories, the Treated $\times$ After coefficient in the last column of Table 4 drops to 29 basis points and remains highly significant. 


\section{Robustness}

In order to test the robustness of our identification strategy, we propose a simple "placebo" test. Specifically, we investigate whether the change in the law has an impact on other loans in our sample that should not have been directly affected. We select all borrowers in our sample that have leasing contracts outstanding in 2004. Leasing contracts should not be affected by the change in the law, since a leased asset, and not a company mortgage, serves as its security. As a result, the change in the law should not have a differential effect on the loan rates charged to the leasing contracts of the nontreated control and the treated groups.

We estimate this premise using the differences-in-differences model presented in equation (1), which includes both loan and year*month fixed effects. The estimates (not reported) corroborate our empirical strategy, as the differences-in-differences estimate is statistically insignificant and economically negligible.

We further subject our results in Table 3 to a number of additional robustness checks (available from the authors upon request). We start by replacing the business loans not secured by company mortgages in the control group by the aforementioned leases (that should not - and are found not - to be affected by the change in the law). Results are unaltered.

Next, we allow for differential trends for treated and control groups. Overall, the results are similar, although the new estimates also indicate that loan rate and borrower limit and rating may adjust more slowly than the other terms. To assess for such a lingering effect of the treatment through time, we allow for a differential impact in the years following the change in law: 2004, 2005 and 2006. Again, we confirm the results, but the estimates of the coefficients on the interactions with the individual year dummies also suggest that the impact on loan rate and borrower limit and rating may 
peak around 2005. Therefore, we reduce the after treatment period to one year, i.e., ending it on December $31^{\text {st }}$, 2004. The estimated effects are again very similar and suggest that other events happening after this date are not driving our findings.

We also investigate whether the change in law led to premature loan terminations, which could introduce attrition bias in our results. ${ }^{34}$ In particular, our results could be biased downwards, if firms terminating loan contracts after 2004 are those that experienced a sharper decline in their collateral values. To address this concern, we start by inspecting whether the number of loan terminations changed abnormally after 2004 , and find no effect. Next, we compute the average internal rating and loan spread of the terminating loans conditional on the termination year. We find no evidence of attrition by observationally riskier borrowers. Finally, to assess the impact of anticipation we introduce an additional moment of treatment in June 2003. Estimates from specifications with two treatments suggest that most of the change in loan terms occurs only after the "true" treatment in 2004.

\section{b. Bank Monitoring}

We analyze how the change in a law, which weakened the value of company mortgages, affected the bank's monitoring activities. To the extent that the change in law could have an ambiguous effect on the bank's monitoring incentives, this is an empirical question. On the one hand, the collateral became less valuable for the bank, which should reduce monitoring. On the other hand, the outstanding loans to these borrowers became relatively riskier, which should increase monitoring.

We analyze the effect of the change in law on the frequency and intensity of the loan officer's revaluation of the assets pledged as collateral and on the frequency of review

\footnotetext{
${ }^{34}$ The bank can require additional collateral within one year following the change in law if it felt that collateralization became too low. If the firm cannot post this requested additional collateral, then the bank can terminate the loan within half a year's notice.
} 
of the borrower's condition. Table 5 provides the comparison of the means for the nontreated control and treated groups, before and after the 2004 change in the law, for our monitoring variables. As before, we prefer to assess the economic effect of the change in the law from a specification that controls simultaneously for individual- and timeheterogeneity. Table 6 displays the results of the full model.

The estimates in Table 6 show that following the 2004 change in the law that reduced the collateral value of company mortgages, the bank monitored this collateral less actively. This conclusion holds for the two measures of monitoring proposed frequency and intensity, and regardless of whether we look at collateral value or at the collateral coverage ratio. ${ }^{35}$ On the one hand, the change in the law led to a stronger reduction in the intensity of the revaluation of collateral for the treated group than for the control group. The estimated differences-in-differences effect suggests that the change in the law decreased the magnitude of collateral revaluations by 2.5 percentage points.

On the other hand, we observe that the change in the law was followed by a significant decrease in the frequency of the revaluation of the assets pledged as collateral. Moreover, the estimated differential decrease in the frequency of 0.64 revaluations per year is economically meaningful, since the average number of collateral revaluations per year in our sample is 2.02 (Table 1). Overall, these findings indicate that the bank reduced its monitoring activity of the collateral following an exogenous decrease in its value.

Next, we turn to the effect of the change in law on the bank's monitoring frequency of the borrower's condition. The relevant model estimates are shown in the last column

\footnotetext{
${ }^{35}$ To the extent that the amortization schedule of our loan contracts is pre-determined, the decrease in loan exposure over time is mechanical. Moreover, we do not observe changes in amortization plans for the group of loans used in our analysis. Therefore, the differential effects we obtain for the collateral coverage ratio cannot be attributed to differential changes in loan exposure across the two groups.
} 
of Table 6 . After the change in the law, the bank revised less frequently the condition of clients that had pledged company mortgages before 2004 than of clients who had not. On average, the bank revises a client's condition approximately every ten months (Table 1). Our differences-in-differences estimates indicate that after 2004 the bank increased the revision interval by about three weeks for the treated group, as opposed to the control group. ${ }^{36}$

We subject our results in Table 6 to the same line-up of robustness checks as for Table 3, i.e., we feature leases in the control group, allow for differential trends and impacts, and reduce the after treatment period to one year. Overall, we find the estimates to be very similar, ${ }^{37}$ allowing us to conclude that the intensity and frequency of the bank's monitoring of the condition of the collateral and borrower is reduced as the value of the company mortgage drops. This result suggests that at least a part of the bank's monitoring activities may be collateral-related and that collateral posting not necessarily makes the bank "lazy."

\section{Conclusion}

Collateral is an important feature of many debt contracts and a feature that has received much attention in the academic literature. However, the intricate nature of collateral such as its joint determination with other contract terms and its impact on borrower and bank behavior imposes steep empirical identification challenges.

\footnotetext{
${ }^{36}$ While the Time to Next Review provides some indication of how often the loan officer analyzes a borrower's file, one could argue that this variable does not say much about how active is the loan officer in learning about the borrower's condition. Therefore, in regressions we leave untabulated we also analyze the effect of the change in the law on ex post measures of monitoring activity. Specifically, we analyze whether the change in the law affects the frequency and intensity with which the bank adjusts loan rates and internal ratings and limits. We compute these measures in the same way as we calculated the collateral monitoring variables (see Table 1). The results are somewhat inconclusive. While the estimated signs corroborate the idea that after the change in the law the bank decreased monitoring effort vis-à-vis borrowers that pledged company mortgages, most estimated coefficients are not statistically significant.

${ }^{37}$ An exception is the estimated impact on the Time to Next Review, which becomes statistically insignificant when we use leases as a control group.
} 
Moreover, accurate data on collateral values, for example, that would enable researchers to start to address these challenges is typically not available.

Our empirical strategy combines two key ingredients that enable us to make progress in empirically assessing the value of collateral. First, we study the impact of a sudden change in a law in Sweden that exogenously reduced the value of company mortgages. The company mortgage is a commonly used means of collateral to secure credit in Sweden, which is similar to the floating lien in the US, the floating charge in the UK, and the chattel mortgage in Australia. The change in the Law on Company Mortgages was implemented on January $1^{\text {st }}$, 2004. Second, we have access to a comprehensive dataset from a major Swedish bank that contains detailed information about the loan contracts, including the regularly updated estimates of the value of the assets pledged to secure each loan.

We study the impact of the change in the law on the bank's business loan portfolio using a differences-in-differences approach. Following the change in the law, we find that the bank reduces the assessed value of collateral and contemporaneously increases the interest rate. The bank lowers its internal credit limit to the borrower, and formally downgrades the borrower. However, the intensity and frequency of the bank's monitoring of the condition of the collateral and borrower is significantly reduced.

Our results indicate that collateral is valuable for the borrower and important for the bank. While pledging high-quality collateral enables borrowers to pay lower loan rates and benefit from increased credit availability, our results also suggest that lenders preserve their incentives to monitor the borrower. As a result, collateral enhances the lenders' role as delegated monitors. 


\section{Table 1 - Variable definitions and descriptive statistics}

The table defines the variables used in the analysis and displays the summary statistics, i.e., the mean, standard deviation (Std. Dev.) and number of observations (Obs.).

\begin{tabular}{|c|c|c|c|c|}
\hline Variable & Definition & Mean & Std. Dev. & Obs. \\
\hline \multicolumn{5}{|l|}{ Loan contract } \\
\hline Collateral value $(€ 000)$ & Estimated value of assets pledged to secure the loan & 49.95 & 184.15 & 108,368 \\
\hline Coverage ratio $(\%)$ & Collateral value / Loan exposure & 46.60 & 46.54 & 108,368 \\
\hline Loan rate $(\%)$ & Annual interest rate of the loan & 6.57 & 1.51 & 108,368 \\
\hline \multicolumn{5}{|l|}{ Borrower } \\
\hline Internal rating & Internal rating assigned by the bank to the borrower $(0-20)$ & 9.29 & 3.23 & 56,696 \\
\hline Internal limit $(€ 000)$ & Maximum exposure towards the borrower & 499.09 & 2616.09 & 99,635 \\
\hline \multicolumn{5}{|l|}{ Monitoring intensity of collateral } \\
\hline Change in collateral value $(\%)$ & Annualized absolute value of the monthly change in collateral value & 6.05 & 19.83 & 107,372 \\
\hline Change in coverage ratio $(\%)$ & Annualized absolute value of the monthly change in coverage ratio & 2.90 & 13.02 & 107,372 \\
\hline \multicolumn{5}{|l|}{ Monitoring frequency of collateral } \\
\hline Nr. changes in collateral value & Number of yearly changes in collateral value & 2.02 & 3.04 & 108,368 \\
\hline $\mathrm{Nr}$. changes in coverage ratio & Number of yearly changes in coverage ratio & 2.35 & 3.97 & 108,368 \\
\hline \multicolumn{5}{|l|}{ Monitoring of borrower } \\
\hline Time to next review (months) & Number of months to next review of the borrower's situation & 10.42 & 3.20 & 94,704 \\
\hline
\end{tabular}




\section{Table 2 - Change in law and credit terms: Comparison of means}

For each dependent variable, the table displays the averages for the non-treated and treated loans and for borrowers before and after the change in company mortgage law on January $1^{\text {st }}$, 2004. Non-treated refers to borrowers that never registered a company mortgage in the period 2000-2006. Treated indicates that the borrower had a company mortgage outstanding on January $1^{\text {st }}$, 2004. After refers to the period 20042006 and Before refers to the year 2003. Standard errors (clustered at the firm level) are provided in parentheses. The symbols ***, **, and * indicate significance at the $1 \%, 5 \%$, and $10 \%$ levels, respectively.

\begin{tabular}{|c|c|c|c|}
\hline & Before & After & Difference \\
\hline \multicolumn{4}{|l|}{$\operatorname{Ln}(1+$ Collateral value $)$} \\
\hline \multirow[t]{2}{*}{ Non-treated loans } & 5.96 & 5.52 & $-0.44 * * *$ \\
\hline & $(5.25)$ & $(5.25)$ & \\
\hline \multirow[t]{2}{*}{ Treated loans } & 6.29 & 5.05 & $-1.24 * * *$ \\
\hline & $(4.95)$ & $(4.94)$ & \\
\hline Difference & 0.33 & -0.47 & $-0.80 * *$ \\
\hline \multicolumn{4}{|l|}{ Coverage ratio $(\%)$} \\
\hline \multirow[t]{2}{*}{ Non-treated loans } & 48.34 & 45.71 & $-2.63 * * *$ \\
\hline & $(46.2)$ & $(46.7)$ & \\
\hline \multirow[t]{2}{*}{ Treated loans } & 51.22 & 43.99 & $-7.23^{* *}$ \\
\hline & $(45.17)$ & $(46.78)$ & \\
\hline Difference & 2.88 & -1.72 & -4.61 \\
\hline \multicolumn{4}{|l|}{ Interest rate $(\%)$} \\
\hline \multirow[t]{2}{*}{ Non-treated loans } & 6.94 & 6.35 & $-0.59 * * *$ \\
\hline & $(1.35)$ & $(1.58)$ & \\
\hline \multirow[t]{2}{*}{ Treated loans } & 7.04 & 6.79 & $-0.25 * * *$ \\
\hline & $(0.97)$ & $(1.06)$ & \\
\hline Difference & 0.10 & $0.44 * * *$ & $0.34 * * *$ \\
\hline \multicolumn{4}{|l|}{ Ln(1 + Internal limit $)$} \\
\hline \multirow[t]{2}{*}{ Non-treated borrowers } & 11.74 & 11.71 & -0.03 \\
\hline & $(1.51)$ & $(1.55)$ & \\
\hline \multirow[t]{2}{*}{ Treated borrowers } & 11.73 & 11.45 & $-0.28 * * *$ \\
\hline & $(1.19)$ & $(1.4)$ & \\
\hline Difference & -0.01 & $-0.26^{* *}$ & $-0.25 * * *$ \\
\hline \multicolumn{4}{|l|}{ Internal Rating } \\
\hline \multirow[t]{2}{*}{ Non-treated borrowers } & 9.67 & 9.41 & $-0.26 * * *$ \\
\hline & $(2.71)$ & $(3.15)$ & \\
\hline \multirow[t]{2}{*}{ Treated borrowers } & 7.08 & 6.08 & $-1.00 * *$ \\
\hline & $(4.14)$ & $(4.58)$ & \\
\hline Difference & $-2.59 * * *$ & $-3.33 * * *$ & -0.73 \\
\hline
\end{tabular}




\section{Table 3 - Change in law and credit terms: Panel analysis}

The table reports the results for regressions of the form: $y_{i t}=\alpha_{i}+\lambda_{t}+\beta$ Treated $_{i} \times$ After $_{t}+u_{i t}$, where $i$ indexes loans or borrowers, $t$ indexes year*month, and $\beta$ is the differences-in-differences estimate of the coefficient on the interaction term of Treated and After. The dependent variables are defined in Table 1. Robust t-statistics (standard errors are clustered at the borrower level) are provided in parentheses. The symbols ***,**, and * indicate significance at the $1 \%, 5 \%$, and $10 \%$ levels, respectively.

\begin{tabular}{|c|c|c|c|c|c|}
\hline \multirow[b]{2}{*}{ Dependent Variable } & \multicolumn{3}{|c|}{ Loan } & \multicolumn{2}{|c|}{ Borrower } \\
\hline & Ln(Collateral $)$ & Coverage ratio & Loan rate & Ln(Internal limit) & Internal rating \\
\hline Treated x After & $-0.75 * * *$ & $-4.15^{* * *}$ & $0.24 * * *$ & $-0.13 * * *$ & $-1.84 * * *$ \\
\hline & $(-11.39)$ & $(-6.73)$ & (18.37) & $(-12.12)$ & $(-32.28)$ \\
\hline Loan fixed effects & Yes & Yes & Yes & No & No \\
\hline Borrower fixed effects & No & No & No & Yes & Yes \\
\hline Year*month fixed effects & Yes & Yes & Yes & Yes & Yes \\
\hline R-squared & 0.03 & 0.01 & 0.25 & 0.06 & 0.05 \\
\hline Number of loans & 3,537 & 3,537 & 3,537 & 3,515 & 2,155 \\
\hline Number of observations & 108,368 & 108,368 & 108,368 & 99,635 & 56,696 \\
\hline
\end{tabular}




\section{Table 4 - Change in law and loan rate controlling for borrower risk: Panel analysis}

The table reports the results for regressions of the form: $y_{i t}=\alpha_{i}+\lambda_{t}+\beta$ Treated $_{i} \times$ After $_{t}+u_{i t}$, where $i$ indexes loans or borrowers, $t$ indexes year*month, and $\beta$ is the differences-in-differences estimate of the coefficient on the interaction term of Treated and After. The dependent variables are defined in Table 1. Robust t-statistics (standard errors are clustered at the borrower level) are provided in parentheses. The symbols $* * *, * *$, and $*$ indicate significance at the $1 \%, 5 \%$, and $10 \%$ levels, respectively.

Dependent Variable Loan rate

\begin{tabular}{|c|c|c|c|c|}
\hline \multirow{2}{*}{$\begin{array}{l}\text { Borrower Risk } \\
\text { Independent Variables }\end{array}$} & \multicolumn{2}{|c|}{ Ln(Internal limit) } & \multicolumn{2}{|c|}{ Internal rating } \\
\hline & (I) & (II) & (I) & (II) \\
\hline \multirow[t]{2}{*}{ Treated $\times$ After } & $0.19 * * *$ & $0.18 * * *$ & $0.39 * * *$ & $0.33 * * *$ \\
\hline & $(12.42)$ & $(11.68)$ & $(20.76)$ & $(17.66)$ \\
\hline \multirow[t]{2}{*}{ Borrower Risk } & & $-0.09 * * *$ & & $-0.03 * * *$ \\
\hline & & $(-19.26)$ & & $(-21.87)$ \\
\hline Loan fixed effects & Yes & Yes & Yes & Yes \\
\hline $\begin{array}{l}\text { Year*month fixed } \\
\text { effects }\end{array}$ & Yes & Yes & Yes & Yes \\
\hline R-squared (\%) & 0.24 & 0.24 & 0.33 & 0.34 \\
\hline Number of loans & 3,491 & 3,491 & 2,083 & 2,083 \\
\hline $\begin{array}{l}\text { Number } \\
\text { observations }\end{array}$ & 99,635 & 99,635 & 56,696 & 56,696 \\
\hline
\end{tabular}




\section{Table 5 - Change in law and monitoring: Comparison of means}

For each dependent variable, the table displays the averages for the non-treated and treated borrowers before and after the change in company mortgage law on January $1^{\text {st }}$, 2004. Non-treated refers to borrowers that never registered a company mortgage in the period 2000-2006. Treated indicates that the borrower had a company mortgage outstanding on January $1^{\text {st }}, 2004$. After refers to the period 2004-2006 and Before refers to the year 2003. Standard errors (clustered at the firm level) are provided in parentheses. The symbols ***, **, and * indicate significance at the $1 \%, 5 \%$, and $10 \%$ levels, respectively.

\begin{tabular}{|c|c|c|c|}
\hline & Before & After & Difference \\
\hline \multicolumn{4}{|c|}{ Absolute change in collateral value $(\%)$} \\
\hline Non-treated borrowers & $\begin{array}{c}5.58 \\
(18.81)\end{array}$ & $\begin{array}{c}5.98 \\
(19.79)\end{array}$ & $0.40 *$ \\
\hline Treated borrowers & $\begin{array}{c}9.90 \\
(25.39)\end{array}$ & $\begin{array}{c}8.50 \\
(23.73)\end{array}$ & -1.40 \\
\hline Difference & $4.32 * * *$ & $2.52 * * *$ & -1.80 \\
\hline \multicolumn{4}{|c|}{ Absolute change in collateral coverage $(\%)$} \\
\hline Non-treated borrowers & $\begin{array}{c}2.65 \\
(11.68)\end{array}$ & $\begin{array}{c}2.87 \\
(13.31)\end{array}$ & $0.22 *$ \\
\hline Treated borrowers & $\begin{array}{c}4.79 \\
(15.31)\end{array}$ & $\begin{array}{c}4.28 \\
(16.22)\end{array}$ & -0.51 \\
\hline Difference & $2.14 * * *$ & $1.41 * * *$ & -0.73 \\
\hline \multicolumn{4}{|c|}{ Number of changes in collateral value } \\
\hline Non-treated borrowers & $\begin{array}{c}2.02 \\
(3.05)\end{array}$ & $\begin{array}{c}1.98 \\
(3.03)\end{array}$ & -0.04 \\
\hline Treated borrowers & $\begin{array}{c}2.68 \\
(3.10)\end{array}$ & $\begin{array}{c}2.27 \\
(3.15)\end{array}$ & -0.41 \\
\hline Difference & $0.66 * * *$ & 0.29 & -0.37 \\
\hline \multicolumn{4}{|c|}{ Number of changes in collateral coverage } \\
\hline Non-treated borrowers & $\begin{array}{c}2.52 \\
(4.09)\end{array}$ & $\begin{array}{c}2.25 \\
(3.92)\end{array}$ & $-0.27 * * *$ \\
\hline Treated borrowers & $\begin{array}{c}3.09 \\
(4.10)\end{array}$ & $\begin{array}{c}2.15 \\
(3.58)\end{array}$ & $-0.94 * * *$ \\
\hline Difference & $0.57 * *$ & -0.10 & $-0.67 * *$ \\
\hline Time to next review & & & \\
\hline Non-treated borrowers & $\begin{array}{l}11.05 \\
(2.71)\end{array}$ & $\begin{array}{l}10.22 \\
(3.30)\end{array}$ & $-0.83 * * *$ \\
\hline Treated borrowers & $\begin{array}{c}9.26 \\
(4.03)\end{array}$ & $\begin{array}{c}9.61 \\
(3.61)\end{array}$ & 0.35 \\
\hline Difference & $-1.79 * * *$ & $-0.61 * * *$ & $1.18 * * *$ \\
\hline
\end{tabular}




\section{Table 6 - Change in law and monitoring: Panel analysis}

The table reports the results for regressions of the form: $y_{i t}=\alpha_{i}+\lambda_{t}+\beta$ Treated $_{i} \times$ After $_{t}+u_{i t}$, where $i$ indexes loans or borrowers, $t$ indexes year*months, and $\beta$ is the differences-in-differences estimate of the coefficient on the interaction term of Treated and After. The dependent variables are defined in Table 1. Robust t-statistics (standard errors are clustered at the borrower level) are provided in parentheses. The symbols ***,**, and * indicate significance at the $1 \%, 5 \%$, and $10 \%$ levels, respectively.

\begin{tabular}{|c|c|c|c|c|c|}
\hline \multirow[b]{2}{*}{ Dependent variable } & \multicolumn{4}{|c|}{ Monitoring of collateral } & \multirow{2}{*}{$\begin{array}{c}\text { Monitoring of borrower } \\
\text { Time to next review }\end{array}$} \\
\hline & Ln(Collateral) & Coverage ratio & Ln(Collateral) & Coverage ratio & \\
\hline \multirow[t]{2}{*}{ Treated x After } & $-2.52 * * *$ & $-1.22 * * *$ & $-0.64 * * *$ & $-0.84 * * *$ & $0.62 * * *$ \\
\hline & $(-5.04)$ & $(-3.50)$ & $(-13.75)$ & $(-15.14)$ & $(6.48)$ \\
\hline Borrower fixed effects & No & No & No & No & Yes \\
\hline Year*month fixed effects & Yes & Yes & Yes & Yes & Yes \\
\hline R-squared & 0.001 & 0.001 & 0.01 & 0.04 & 0.08 \\
\hline
\end{tabular}




\section{References}

Altman, E. I., and E. Kalotay, 2010, A Flexible Approach to Modeling Ultimate Recoveries on Defaulted Loans and Bonds, New York University, New York.

Argentiero, A., 2009, Some New Evidence on the Role of Collateral: Lazy Banks or Diligent Banks?, Institute for Studies and Economic Analyses, Rome.

Barclay, M. J., and C. W. Smith, 1995, "The Maturity Structure of Corporate Debt," Journal of Finance 50, 609-631.

Beck, T., A. Demirgüç-Kunt, and R. Levine, 2005, "Financial and Legal Constraints to Firm Growth. Does Firm Size Matter?," Journal of Finance 60, 137-177.

Berger, A. N., S. Frame, and V. P. Ioannidou, 2010, "Tests of Ex Ante versus Ex Post Theories of Collateral using Private and Public Information," Journal of Financial Economics Forthcoming.

Berger, A. N., and G. F. Udell, 1990, "Collateral, Loan Quality and Bank Risk," Journal of Monetary Economics 25, 21-42.

Berger, A. N., and G. F. Udell, 1995, "Relationship Lending and Lines of Credit in Small Firm Finance," Journal of Business 68, 351-381.

—, 2006, "A More Complete Conceptual Framework for SME Finance," Journal of Banking and Finance 30, 2945-2966.

Berglöf, E., and E. L. von Thadden, 1994, "Short-Term Versus Long-Term Interests: Capital Structure with Multiple Investors," Quarterly Journal of Economics 109, 1055-1084.

Berkovitch, E., and E. H. Kim, 1990, "Financial Contracting and Leverage Induced Over- and Under-Investment Incentives," Journal of Finance 45, 765-794.

Bernanke, B. S., and M. Gertler, 1989, "Agency Costs, Net Worth, and Business Fluctuations," American Economic Review 79, 14-31.

Bernanke, B. S., M. Gertler, and S. Gilchrist, 1996, "The Financial Accelerator and the Flight to Quality," Review of Economics and Statistics 78, 1-15.

Bertrand, M., E. Duflo, and S. Mullainathan, 2004, "How Much Should We Trust Differences-in-Differences Estimates?," Quarterly Journal of Economics 119, 249275.

Bester, H., 1985, "Screening vs. Rationing in Credit Markets with Imperfect Information," American Economic Review 75, 850-855.

Bharath, S. T., S. Dahiya, A. Saunders, and A. Srinivasan, 2007, "So What Do I Get: A Bank's View of Lending Relationships," Journal of Financial Economics 85, 368-419.

Boot, A. W. A., A. Thakor, and G. Udell, 1991, "Credible Commitments, Contract Enforcement Problems and Banks: Intermediation as Credible Insurance," Journal of Banking and Finance 15, 605-632.

Boot, A. W. A., and A. V. Thakor, 1994, "Moral Hazard and Secured Lending in an Infinitely Repeated Credit Market Game," International Economic Review 35, 899920.

Brick, I. E., and D. Palia, 2007, "Evidence of Jointness in the Terms of Relationship Lending," Journal of Financial Intermediation 16, 452-476.

Chan, Y.-S., and A. V. Thakor, 1987, "Collateral and Competitive Equilibria with Moral Hazard and Private Information," Journal of Finance 42, 345-363.

Degryse, H., V. Ioannidou, and E. von Schedvin, 2011, On the Non-Exclusivity of Loan Contracts: An Empirical Investigation, Tilburg University, Tilburg.

Degryse, H., M. Kim, and S. Ongena, 2009, Microeconometrics of Banking: Methods, Applications and Results, Oxford University Press. 
Dennis, S., D. Nandy, and I. Sharpe, 2000, "The Determinants of Contrac Terms in Bank Revolving Credit Agreements," Journal of Financial and Quantitative Analysis 35, 87-110.

Diamond, D. W., 1984, "Financial Intermediation and Delegated Monitoring," Review of Economic Studies 51, 393-414.

Djankov, S., O. Hart, C. McLiesh, and A. Shleifer, 2008, "Debt Enforcement around the World," Journal of Political Economy 116, 1105-1149.

Djankov, S., R. La Porta, F. Lopez-de-Silanes, and A. Shleifer, 2003, "Courts," Quarterly Journal of Economics 118, 453-518.

Eckbo, B. E., and K. S. Thorburn, 2009, "Bankruptcy as an Auction Process: Lessons from Sweden," Journal of Applied Corporate Finance 21, 36-50.

Eckbo, E., B., and K. S. Thorburn, 2003, "Control Benefits and CEO Discipline in Automatic Bankruptcy Auctions," Journal of Financial Economics 69, 227-258.

Franks, J., and O. Sussman, 2005, "Financial Distress and Bank Restructuring of Small to Medium Size UK Companies," Review of Finance 9, 65-96.

Freixas, X., and J. C. Rochet, 2008, Microeconomics of Banking (2), MIT Press, Cambridge MA.

Gennaioli, N., and S. Rossi, 2009, Contractual Resolutions of Financial Distress, CREI Universitat Pompeu Fabra, Barcelona.

Gompers, P. A., 1995, "Optimal Investment, Monitoring, and the Staging of Venture Capital," Journal of Finance 50, 1461-1489.

Gorton, G., and J. Kahn, 2000, "The Design of Bank Loan Contracts," Review of Financial Studies 13, 331-364.

Hackbarth, D., C. A. Hennessy, and H. E. Leland, 2007, "Can the Trade-off Theory Explain Debt Structure?," Review of Financial Studies 20, 1389-1428.

Harhoff, D., and T. Körting, 1998, "Lending Relationships in Germany - Empirical Evidence from Survey Data," Journal of Banking and Finance 22, 1317-1353.

Haselmann, R. F. H., K. Pistor, and V. Vig, 2010, "How Law Affects Lending," Review of Financial Studies 23, 549-580.

Jiménez, G., V. Salas, and J. Saurina, 2006, "Determinants of Collateral," Journal of Financial Economics 81, 255-281.

Khieu, H., and D. J. Mullineaux, 2009, The Determinants of Bank Loan Recovery Rates, University of Southern Indiana, Evansville IN.

Kiyotaki, N., and J. Moore, 1997, "Credit Cycles," Journal of Political Economy 105, 211-248.

La Porta, R., F. Lopez-de-Silanes, A. Shleifer, and R. W. Vishny, 1997, "Legal Determinants of External Finance," Journal of Finance 22, 1131-1150.

_ , 1998, "Law and Finance," Journal of Political Economy 106, 1113-1155.

Lacker, J. M., 2001, "Collateralized Debt as the Optimal Contract," Review of Economic Dynamics 4, 842-859.

Levine, R., 1999, "Law, Finance, and Economic Growth," Journal of Financial Intermediation 8, 8-35.

Liberti, J. M., and A. Mian, 2010, "Collateral Spread and Financial Development," Journal of Finance 65, 147-178.

Longhofer, S. D., and J. A. C. Santos, 2000, "The Importance of Bank Seniority for Relationship Lending," Journal of Financial Intermediation 9, 57-89.

Manove, M. A., A. J. Padilla, and M. Pagano, 2001, "Collateral versus Project Screening: A Model of Lazy Banks," RAND Journal of Economics 32, 726-744.

Matsuyama, K., 2007, "Credit Traps and Credit Cycles," American Economic Review 97, 503-516. 
Melnik, A., and S. Plaut, 1986, "Loan Commitment Contracts, Terms of Lending, and Credit Allocation," Journal of Finance 41, 425-435.

Mester, L. J., L. Nakamura, and M. Renault, 2007, "Transactions Accounts and Loan Monitoring," Review of Financial Studies 20, 529-556.

Norden, L., and M. Weber, 2010, "Credit Line Usage, Checking Account Activity, and Default Risk of Bank Borrowers," Review of Financial Studies 23, 3665-3699.

Ono, A., and I. Uesugi, 2009, "The Role of Collateral and Personal Guarantees in Relationship Lending: Evidence from Japan's SME Loan Market," Journal of Money, Credit, and Banking 41, 935-960.

Park, C., 2000, "Monitoring and Structure of Debt Contracts," Journal of Finance 55, 2157-2195.

Rajan, R. G., and A. Winton, 1995, "Covenants and Collateral as Incentives to Monitor," Journal of Finance 50, 1113-1146.

Repullo, R., and J. Suarez, 1998, "Monitoring, Liquidation, and Security Design," Review of Financial Studies 11, 163-187.

Rodano, G., N. Serrano-Velarde, and E. Tarantino, 2011, The Causal Effect of Bankruptcy Law on the Cost of Finance, Bank of Italy, Rome.

Smith, C. J., and J. B. Warner, 1979, "Bankruptcy, Secured Debt. and Optimal Capital Structure: Comment," Journal of Finance 34, 247-251.

Strömberg, P., 2000, "Conflicts of Interest and Market Illiquidity in Bankruptcy Auctions: Theory and Tests," Journal of Finance 55, 2641-2691.

Stulz, R. M., and H. Johnson, 1985, "An Analysis of Secured Debt," Journal of Financial Economics 14, 501-521.

Thorburn, K. S., 2000, "Bankruptcy Auctions: Costs, Debt Recovery, and Firm Survival," Journal of Financial Economics 58, 337-368.

Vafeas, N., 1999, "Board Meeting Frequency and Firm Performance," Journal of Financial Economics 53, 113-142.

Vig, V., 2011, Access to Collateral and Corporate Debt Structure: Evidence from a Natural Experiment, London Business School, London. 


\section{Earlier Working Papers:}

For a complete list of Working Papers published by Sveriges Riksbank, see www.riksbank.se

Estimation of an Adaptive Stock Market Model with Heterogeneous Agents by Henrik Amilon ........ 2005:177

Some Further Evidence on Interest-Rate Smoothing: The Role of Measurement

Errors in the Output Gap by Mikael Apel and Per Jansson.....

Bayesian Estimation of an Open Economy DSGE Model with Incomplete Pass-Through

by Malin Adolfson, Stefan Laséen, Jesper Lindé and Mattias Villani

Are Constant Interest Rate Forecasts Modest Interventions? Evidence from

an Estimated Open Economy DSGE Model of the Euro Area by Malin Adolfson,

Stefan Laséen, Jesper Lindé and Mattias Villani

Inference in Vector Autoregressive Models with an Informative

Prior on the Steady State by Mattias Villani

Bank Mergers, Competition and Liquidity by Elena Carletti, Philipp Hartmann

and Giancarlo Spagnolo

Testing Near-Rationality using Detailed Survey Data

by Michael F. Bryan and Stefan Palmqvist....

Exploring Interactions between Real Activity and the Financial Stance

by Tor Jacobson, Jesper Lindé and Kasper Roszbach

Two-Sided Network Effects, Bank Interchange Fees,

and the Allocation of Fixed Costs by Mats A. Bergman

Trade Deficits in the Baltic States: How Long Will the Party Last?

by Rudolfs Bems and Kristian Jönsson.

Real Exchange Rate and Consumption Fluctuations follwing Trade Liberalization

Modern Forecasting Models in Action: Improving Macroeconomic Analyses at Central Banks

by Malin Adolfson, Michael K. Andersson, Jesper Lindé, Mattias Villani and Anders Vredin.

Bayesian Inference of General Linear Restrictions on the Cointegration Space by Mattias Villani ....... 2005:189

Forecasting Performance of an Open Economy Dynamic Stochastic General Equilibrium Model

by Malin Adolfson, Stefan Laséen, Jesper Lindé and Mattias Villani

Forecast Combination and Model Averaging using Predictive Measures

by Jana Eklund and Sune Karlsson

Swedish Intervention and the Krona Float, 1993-2002

by Owen F. Humpage and Javiera Ragnartz....

A Simultaneous Model of the Swedish Krona, the US Dollar and the Euro

by Hans Lindblad and Peter Sellin....

2006:193

Testing Theories of Job Creation: Does Supply Create Its Own Demand?

by Mikael Carlsson, Stefan Eriksson and Nils Gottfries....

Down or Out: Assessing The Welfare Costs of Household Investment Mistakes

by Laurent E. Calvet, John Y. Campbell and Paolo Sodini

Efficient Bayesian Inference for Multiple Change-Point and Mixture Innovation Models

by Paolo Giordani and Robert Kohn

Derivation and Estimation of a New Keynesian Phillips Curve in a Small Open Economy

by Karolina Holmberg....

Technology Shocks and the Labour-Input Response: Evidence from Firm-Level Data

by Mikael Carlsson and Jon Smedsaas

Monetary Policy and Staggered Wage Bargaining when Prices are Sticky

by Mikael Carlsson and Andreas Westermark

The Swedish External Position and the Krona by Philip R. Lane

2006:200

Price Setting Transactions and the Role of Denominating Currency in FX Markets

by Richard Friberg and Fredrik Wilander....

2007:201

The geography of asset holdings: Evidence from Sweden

by Nicolas Coeurdacier and Philippe Martin

Evaluating An Estimated New Keynesian Small Open Economy Model

by Malin Adolfson, Stefan Laséen, Jesper Lindé and Mattias Villani .....

The Use of Cash and the Size of the Shadow Economy in Sweden

by Gabriela Guibourg and Biörn Segendorf

Bank supervision Russian style: Evidence of conflicts between micro- and macro-

prudential concerns by Sophie Claeys and Koen Schoors 
Optimal Monetary Policy under Downward Nominal Wage Rigidity

by Mikael Carlsson and Andreas Westermark.

Financial Structure, Managerial Compensation and Monitoring

by Vittoria Cerasi and Sonja Daltung

Financial Frictions, Investment and Tobin's q by Guido Lorenzoni and Karl Walentin

Sticky Information vs. Sticky Prices: A Horse Race in a DSGE Framework

by Mathias Trabandt.

Acquisition versus greenfield: The impact of the mode of foreign bank entry

on information and bank lending rates by Sophie Claeys and Christa Hainz

Nonparametric Regression Density Estimation Using Smoothly Varying Normal Mixtures

by Mattias Villani, Robert Kohn and Paolo Giordani

The Costs of Paying - Private and Social Costs of Cash and Card

by Mats Bergman, Gabriella Guibourg and Biörn Segendorf....

Using a New Open Economy Macroeconomics model to make real nominal

exchange rate forecasts by Peter Sellin

Introducing Financial Frictions and Unemployment into a Small Open Economy Model

by Lawrence J. Christiano, Mathias Trabandt and Karl Walentin

Earnings Inequality and the Equity Premium by Karl Walentin

2007:215

Bayesian forecast combination for VAR models by Michael K Andersson and Sune Karlsson.

2007:216

Do Central Banks React to House Prices?

by Daria Finocchiaro and Virginia Queijo von Heideken

The Riksbank's Forecasting Performance

by Michael K. Andersson, Gustav Karlsson and Josef Svensson

2007:218

Macroeconomic Impact on Expected Default Freqency

by Per Åsberg and Hovick Shahnazarian

Monetary Policy Regimes and the Volatility of Long-Term Interest Rates

by Virginia Queijo von Heideken

Governing the Governors: A Clinical Study of Central Banks

by Lars Frisell, Kasper Roszbach and Giancarlo Spagnolo .....

The Monetary Policy Decision-Making Process and the Term Structure of Interest Rates

by Hans Dillén

How Important are Financial Frictions in the U.S. and the Euro Area

by Virginia Queijo von Heideken

Block Kalman filtering for large-scale DSGE models by Ingvar Strid and Karl Walentin

Optimal Monetary Policy in an Operational Medium-Sized DSGE Model

by Malin Adolfson, Stefan Laséen, Jesper Lindé and Lars E.O. Svensson

Firm Default and Aggregate Fluctuations by Tor Jacobson, Rikard Kindell, Jesper Lindé and Kasper Roszbach

Re-Evaluating Swedish Membership in EMU: Evidence from an Estimated Model

by Ulf Söderström

The Effect of Cash Flow on Investment: An Empirical Test of the Balance Sheet Channel

by Ola Melander.

Expectation Driven Business Cycles with Limited Enforcement

by Karl Walentin

Effects of Organizational Change on Firm Productivity

by Christina Håkanson

Evaluating Microfoundations for Aggregate Price Rigidities: Evidence from Matched Firm-Level

Data on Product Prices and Unit Labor Cost by Mikael Carlsson and Oskar Nordström Skans

Monetary Policy Trade-Offs in an Estimated Open-Economy DSGE Mode

by Malin Adolfson, Stefan Laséen, Jesper Lindé and Lars E.O. Svensson

Flexible Modeling of Conditional Distributions Using Smooth Mixtures of Asymmetric

Student T Densities by Feng Li, Mattias Villani and Robert Kohn.

Forecasting Macroeconomic Time Series with Locally Adaptive Signal Extraction

by Paolo Giordani and Mattias Villani.

Evaluating Monetary Policy by Lars E.O. Svensson

2009:235 
Risk Premiums and Macroeconomic Dynamics in a Heterogeneous Agent Model by Ferre De Graeve, Maarten Dossche, Marina Emiris, Henri Sneessens and Raf Wouters....

Picking the Brains of MPC Members by Mikael Apel, Carl Andreas Claussen and Petra Lennartsdotter.

Involuntary Unemployment and the Business Cycle by Lawrence J. Christiano,

Mathias Trabandt and Karl Walentin

Housing collateral and the monetary transmission mechanism by Karl Walentin and Peter Sellin.

The Discursive Dilemma in Monetary Policy by Carl Andreas Claussen and Øistein Røisland.

Monetary Regime Change and Business Cycles by Vasco Cúrdia and Daria Finocchiaro. 2010:241 Bayesian Inference in Structural Second-Price common Value Auctions by Bertil Wegmann and Mattias Villani

Equilibrium asset prices and the wealth distribution with inattentive consumers

by Daria Finocchiaro.

Identifying VARs through Heterogeneity: An Application to Bank Runs

by Ferre De Graeve and Alexei Karas.

Modeling Conditional Densities Using Finite Smooth Mixtures

by Feng Li, Mattias Villani and Robert Kohn

The Output Gap, the Labor Wedge, and the Dynamic Behavior of Hours

by Luca Sala, Ulf Söderström and Antonella Trigari

Density-Conditional Forecasts in Dynamic Multivariate Models

by Michael K. Andersson, Stefan Palmqvist and Daniel F. Waggoner

Anticipated Alternative Policy-Rate Paths in Policy Simulations

by Stefan Laséen and Lars E.O. Svensson

MOSES: Model of Swedish Economic Studies by Gunnar Bårdsen, Ard den Reijer

Patrik Jonasson and Ragnar Nymoen

The Effects of Endogenuos Firm Exit on Business Cycle Dynamics and Optimal

Fiscal Policy by Lauri Vilmi

Parameter Identification in a Estimated New Keynesian Open Economy Model

by Malin Adolfson and Jesper Lindé.....

Up for count? Central bank words and financial stress by Marianna Blix Grimaldi

Wage Adjustment and Productivity Shocks

by Mikael Carlsson, Julián Messina and Oskar Nordström Skans

Stylized (Arte) Facts on Sectoral Inflation by Ferre De Graeve and Karl Walentin

Hedging Labor Income Risk by Sebastien Betermier, Thomas Jansson,

Christine A. Parlour and Johan Walden

Taking the Twists into Account: Predicting Firm Bankruptcy Risk with Splines of Financial Ratios by Paolo Giordani, Tor Jacobson, Erik von Schedvin and Mattias Villani 
Sveriges Riksbank

Visiting address: Brunkebergs torg 11

Mail address: se-103 37 Stockholm

Website: www.riksbank.se

Telephone: +46878700 00, Fax: +468210531

E-mail: registratorn@riksbank.se 